\title{
VIABILITY OF THE USE OF AFRICAN MAHOGANY WITH CUPUASSU TREE IN AGROFORESTRY SYSTEM (AFS)
}

\author{
Rafael Moysés Alves ${ }^{2}$, Saulo Fabrício da Silva Chaves ${ }^{3 *} \bullet$ and Abel Jamir Ribeiro Bastos ${ }^{3} \oplus$
}

\author{
${ }^{1}$ Received on 19.07.2019 accepted for publication on 02.12.2019. \\ ${ }^{2}$ Empresa Brasileira de Pesquisa Agropecuária, Belém , PA - Brasil. E-mail: <rafael-moyses.alves@embrapa.br>. \\ ${ }^{3}$ Universidade Federal de Viçosa, Programa de Pós-Graduação em Genética e Melhoramento de Plantas, Viçosa , MG - Brasil. E-mail: \\ <saulofabricioagro@gmail.com> and < abel.bastos.ufra@gmail.com>. \\ *Corresponding author.
}

\begin{abstract}
The objective of this work was to study the behavior of cupuassu trees intercropped with African mahogany in order to define the viability of using these species in AFS and to evaluate the performance of African mahogany itself, aiming its application in reforestation projects. Both species were tested in the municipality of Tomé Açu - PA, between 2005 and 2016. In addition to these two species, banana and black pepper were also part of the AFS initially. Four levels of influence of mahogany on cupuassu trees were evaluated, defined by the proximity between plants. The vegetative development of both species was measured, as well as the production of eight harvests and the mortality rate of the cupuassu trees. The results showed that the competition exerted by African mahogany did not affect the vegetative development of cupuassu trees. In the productive phase, up to the fourth harvest, the competition was not harmful as it didn't reduce production. However, from the fifth harvest on, cupuassu trees closest to African mahogany trees showed a significant reduction in fruit production and, from the sixth harvest on, all plants were affected, regardless of proximity. On the other hand, consistent vegetative development of African mahogany was observed, which allows its use in silvicultural projects in this region. We concluded that African mahogany had a negative influence on cupuassu trees. Further studies are needed to assess whether the development of African mahogany economically compensates for the decline in cupuassu production.
\end{abstract}

Keywords: Khaya ivorensis, Theobroma grandiflorum, Consortium.

\section{VIABILIDADE DA UTILIZAÇÃO DE MOGNO AFRICANO COM CUPUAÇUZEIRO EM SISTEMAS AGROFLORESTAIS (SAF)}

\begin{abstract}
RESUMO - O objetivo deste trabalho foi estudar o comportamento do cupuaçuzeiro consorciado com mogno africano, a fim de definir a viabilidade do uso destas espécies em SAF e avaliar o desempenho do mogno africano em si, visando sua aplicação em programas de reflorestamento. Ambas as espécies foram avaliadas em um ensaio no município de Tomé Açu - PA, entre 2005 e 2016. Além destas duas espécies, bananeira e pimenteira do reino também faziam parte do SAF, inicialmente. Foram avaliados quatro níveis de influência do mogno sobre o cupuaçuzeiro, definidos pela proximidade entre as plantas. Foram mensurados o desenvolvimento vegetativo de ambas as espécies, bem como a produção de frutos em oito safras e a taxa de mortalidade do cupuaçuzeiro. Os resultados mostraram que a competição exercida pelo mogno africano não afetou o desenvolvimento vegetativo do cupuaçuzeiro. Na fase produtiva, até a quarta safra, a competição não era prejudicial, pois não reduzia a produção de frutos. Entretanto, a partir da quinta safra, os cupuaçuzeiros mais próximos das plantas de mogno africano apresentaram redução significativa na produção de frutos e, a partir da sexta safra, todas as plantas foram afetadas, independentemente da proximidade. Por outro lado, foi observado desenvolvimento vegetativo consistente do mogno africano, o que permite seu uso em projetos silviculturais nessa região. Concluiu-se que o mogno africano exerceu influência negativa sobre as cupuaçuzeiro. Mais estudos são necessários para avaliar se o desenvolvimento do mogno africano compensa economicamente o declínio na produção de cupuaçu.
\end{abstract}

Palavras-Chave: Khaya ivorensis, Theobroma grandiflorum, Consórcio. 


\section{INTRODUCTION}

In agroforestry systems - AFSs, as in any agricultural crop, cost and benefit factors should always be taken into account, since AFSs have both biological and economic advantages and disadvantages (Macdicken and Vergara, 1990).

In the Amazonian biome, where there is combination of intense rains and soils with low organic matter and natural fertility, priority should be given to agricultural crops that protect the soil and recycle nutrients. In this context, according to Alvim (1990), agroforestry systems would be the best alternative for the use of Amazonian soils, as long as its components have agronomic, economic and ecological values to guarantee environmental sustainability.

Land use intensification, with consequent increase in productivity is among the advantages of using AFSs in the Amazon region. It also promotes the balance of agro-systems, reducing the risks of epidemics, reducing production costs and improving the quality of life of farmers (Falesi and Baena, 1999).

In the state of Pará, agroforestry systems gained special prominence from the end of the 1950's in the municipality of Tomé-Açu. The species initially prioritized were black pepper (Piper nigrum L.), cacao (Theobroma cacao L.), oil palm (Elais guineensis Jacq.), andiroba (Carapa guianensis Aubl.), rubber tree (Hevea brasiliensis (Willd. Ex Adr de Juss.) Muell. Arg.), papaya (Carica papaya L.) and passion fruit (Passiflora edulis Sims.) (Arco-Verde, 2008). However, from the 1980's on, perennial fruit trees such as cupuassu tree (Theobroma grandiflorum (Willd. ex. Spreng.) Schum), yellow mombin (Spondias mombin L.), acaí (Euterpe oleraceae Mart.), acerola (Malpighia emarginata DC.), orange (Citrus x sinensis Macfad.), among others, also gained prominence, which enabled production diversification that, together with agroforestry systems, increased the local economy (Bolfe and Batistella, 2011).

Sanguino et al. (2007), Abdo et al. (2008), Varela and Santana (2009) reported the economic viability of AFSs. The authors showed the preference of producers for agroforestry systems probably due to the possibility of production diversification, which implies in a lower market risk and better temporal distribution of gains. It is also noteworthy that the major bottlenecks for the maintenance of this system are labor and machinery availability, as well as the cost of land when it is leased.
African mahogany (Khaya ivorensis A. Chev.) is a large plant belonging to family Meliaceae, order Sapindales (Chase et al., 2016). The tree is economically important due to the quality of its wood, which is widely used in civil and naval construction (França et al., 2015). The species originates in Africa, specifically in the continent western coast and, therefore, is exotic to the Brazilian biome (Verzignassi et al., 2009). It was introduced in the country to replace Brazilian Big Leaf mahogany plantations (Swietenia macrophylla King), because, in addition to having wood with similar physicochemical properties, the African species is resistant to the mahogany borer (Hypsiphyla grandella Zeller), the main pest of the Brazilian species. The use of $K$. ivorensis in several crop systems in Pará replacing the Brazilian native species has already become quite widespread, in spite of presenting low genetic base (Lunz et al., 2009). In addition, it has fast growth and can be exploited as legal timber, since the Brazilian government has stipulated standards that restrict the exploitation of native timber species (Castro et al., 2008; Soares, 2014).

Cupuassu tree is a fruit species of the order Malvales, family Malvaceae, and subfamily Sterculioideae (Chase et al., 2016). It originates in the Amazon region, where it occurs spontaneously in areas of primary forest. According to Venturieri (2011), the species is often recommended to compose agroforestry systems due to its tolerance to shading, presenting good productivity in these systems. Fruit pulp has both economic and nutritional value, being used by the food industry for the manufacture of juices, ice cream, jellies and sweets. Seeds are used by cosmetic and pharmaceutical industries, as well as for the manufacture of a product similar to chocolate, called "cupulate" (Genovese and Lannes, 2009; Oliveira and Genovese, 2013).

The aim of this study was to evaluate the influence of African mahogany on vegetative development, fruit production and survival rate of cupuassu trees; and to verify the viability of using both species in agroforestry systems.

\section{MATERIAL AND METHODS}

The experiment was carried out in 2005 in a commercial plantation in the municipality of Tomé Açu, state of Pará. This municipality presents average annual rainfall of $2.716 \mathrm{~mm}$, average relative humidity of $85 \%$ and average temperature of $26,4^{\circ} \mathrm{C}$, being

Revista Árvore 2020;44:e4407 
classified in the Ami climatic type, according to Köppen classification and B2 rAa', according to Thornthwaite classification (Pachêco and Bastos, 2001). Soil was classified as Yellow Latosol with medium texture.

The Agroforestry System (AFS) implantation occurred with the simultaneous planting of black pepper, in double $2 \mathrm{~m} \times 2 \mathrm{~m}$ lines $4 \mathrm{~m}$ away from each other; banana tree (Musa spp.) with spacing of $6 \mathrm{~m} \mathrm{x} 4 \mathrm{~m}$; cupuassu tree with spacing of $6 \mathrm{~m} \times 4 \mathrm{~m}$ and African mahogany with spacing of $18 \mathrm{~m} \times 10 \mathrm{~m}$. Rice (Oryza spp.) (First semester) and pigeon peas (Cajanus cajan L. Millsp.) (Second semester) were planted between banana and black pepper lines in the first year. The intense shading promoted by the plants, from the second year disallowed new plantings. Both cupuassu tree and African mahogany were planted with ungrafted seedlings (progenies) prepared in nursery in 2004 and taken to the field at about ten months of age.

The thinning dynamics of temporary crops started in the fourth year of planting, and by the end of the sixth year, banana plants had already been removed. The same occurred for black pepper that, affected by the fusariose disease (Fusarium solani (Mart.) Appel \& Wr. emend.
Snyd. \& Hans. f. sp. piperis), remained in the field until the seventh year. Thus, from that period, only African mahogany and cupuassu trees remained in the area.

In order to verify the possible competition of African mahogany on cupuassu tree, the distances between plants of these two species were established as treatments. Thus, cupuassu trees were stratified and measured at four distances from African mahogany plants, setting evaluation levels (Figure 1): Level $1=$ $3.6 \mathrm{~m}$; Level $2=6.7 \mathrm{~m}$; Level $3=9.2 \mathrm{~m}$; Level $4=$ $13.4 \mathrm{~m}$ (control) in which each evaluation level was composed of four equally spaced cupuassu trees. Thus, 16 cupuassu trees were measured in relation to each mahogany plant. Of the 24 available mahogany trees, a sample of 9 plants was used, since they met the level distribution model requirements (Figure 1). In total, 144 cupuassu trees were evaluated.

The following response variables were used to evaluate cupuassu trees: plant height $(\mathrm{m})$; stem diameter at $50 \mathrm{~cm}$ from the soil $(\mathrm{cm})$; number of fruits; mean weight of fruits and fruit production estimation $(\mathrm{kg} /$ plant/harvest). The historical production series was constructed through the measurement of eight harvests

Source: Embrapa Amazônia Oriental.

Fonte: Embrapa Amazônia Oriental.

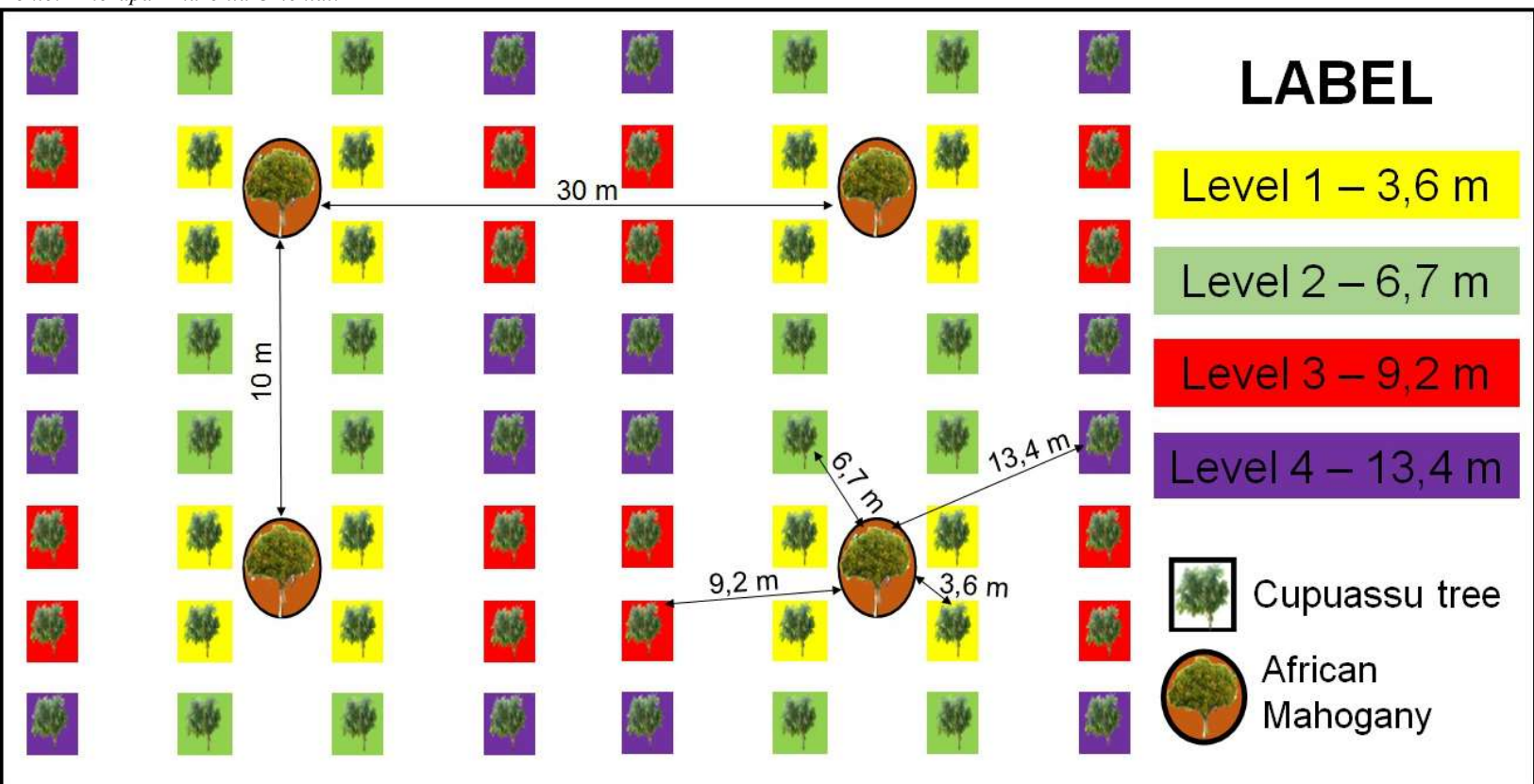

Figure 1 - Scheme of the distribution of AFS plants in the field, which defined the four distance levels of African mahogany plants from cupuassu trees in an agroforestry system installed in Tomé Açu with these two species. Belém - PA, 2019.

Figura 1 - Esquema da distribuição dos componentes do SAF no campo, o qual definiu os quatro níveis de distância das plantas de Mogno Africano com relação ao cupuaçuzeiro, em um sistema agroflorestal instalado em Tomé-Açu com estas duas espécies. Belém - PA, 2019. 
between 2007 and 2015: 2007/2008, 2008/2009, 2009/2010, 2010/2011, 2011/2012, 2012/2013, $2013 / 2014$ and $2014 / 2015$. For a more accurate fruit production estimation to be used in the comparison of levels, only the average of the last five harvests was used, when there is usually greater stability in cupuassu production. The final mortality rate of plants was estimated at the four levels of proximity to mahogany.

The following parameters were measured in African mahogany: total plant height $(\mathrm{m})$ in the first eight years of field, diameter (m) at breast height (DBH) in the eleven experimental years, canopy diameter (m) and canopy area $\left(\mathrm{m}^{2}\right)$ in the last four years. In addition, the commercial wood volume was estimated, through a formula found by Silva et al. (2016) (Equation 1), with an $\mathrm{R}^{2}$ of $96 \%$.

Equation 1. Commercial wood volume estimation $v=\exp (-9,792156+2,022933 \ln ($ dap $)+0,813326 \ln (h t)) \quad$ Eq. 1

Data were submitted to analysis of variance (ANOVA) followed by Tukey test to compare means at
$5 \%$ probability level. These analyses were performed using the GENES statistical software, version 2014.6.1 (Cruz, 2013).

\section{RESULTS}

It was observed that, during the trial, rainfall was abundant from January to June, and declined sharply in the second semester, when flowering and fruiting usually occur. The amount and distribution of rainfall during this period influenced the establishment and field development of AFS plants in the initial years, and later fruit production, when competition between species became more intense.

However, in the first two years ofAFS establishment, there was no interference on the development of cupuassu trees closest to mahogany in relation to those more distant, both in height and stem diameter. This indicates that in the first years of AFS establishment, there was no competition for light (shoots), water and nutrients (roots).

Source: Embrapa Amazônia Oriental.

Fonte: Embrapa Amazônia Oriental.

Level 1 Level 2 LLevel 3 Level 4

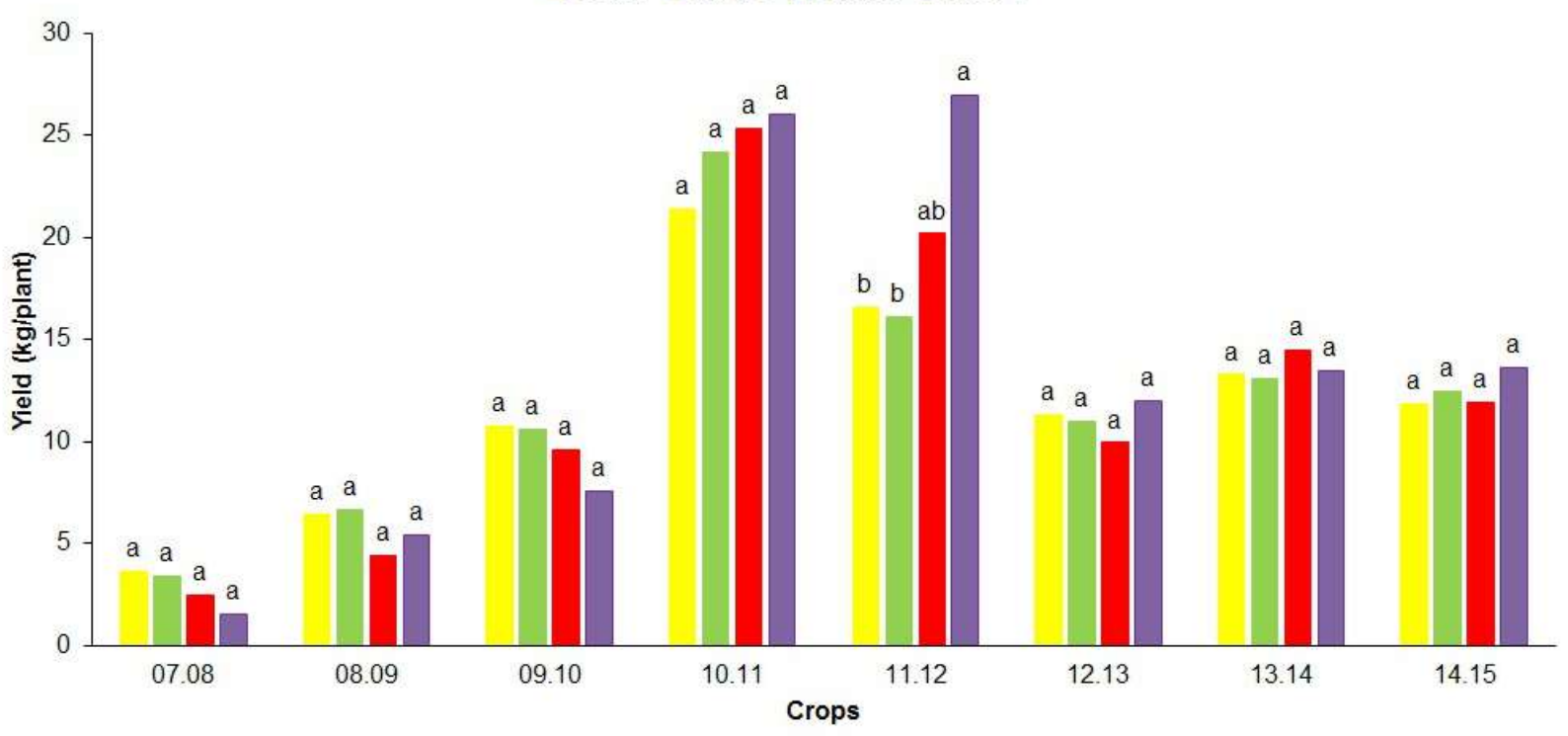

Figure 2 - Evolution of cupuassu fruit production ( $\mathrm{kg} / \mathrm{plant}$ / harvest) in the first eight harvests, according to the four levels of competition established with African mahogany trees in AFS in the municipality of Tomé Açu with cupuassu and African mahogany trees. Belém - PA, 2019.

Figura 2 - Evolução da produção de frutos do cupuaçuzeiro (kg/planta/safra) nas primeira oito safras, de acordo com os quatro níveis de competição com mogno africano estabelecidos, em um SAF no município de Tomé Açu com cupuaçuzeiro e mogno africano. Belém - PA, 2019.

Revista Árvore 2020;44:e4407 
The production of cupuassu fruits began in the third year of field. Production, along the harvests and by levels of distance, are shown in Figure 2.

In the four initial harvests, it was not possible to observe any decrease in fruit production due to competition with African mahogany, following the same result previously reported for vegetative development. That is, both cupuassu trees $3.6 \mathrm{~m}$ and $13.4 \mathrm{~m}$ away from mahogany trees had similar yields. The competition only became observable from the fifth crop (11/12), in which it was possible to observe that cupuassu trees far from mahogany plants (level 4) maintained the production of previous year, while closer ones (levels 1, 2 and 3) suffered from productive depression. In subsequent harvests, there was a competition intensification.

It is worth mentioning that during the first five years of field, the AFS was provided of water supplementation, done in the second half of the year, a period characterized by the water deficit in the study region. From 2011, irrigation was removed. This fact intensified competition between plants of both species, reducing the production capacity of cupuassu trees (Figure 2).

The production of cupuassu trees at different competition levels with African mahogany was compared during the last five harvests, a period expected as of productive stability. No difference in fruit production

Table 1 - Average cupuassu tree fruit production, in $\mathrm{kg} / \mathrm{plant}$, in the last five harvests $(2010 / 2011$ to 2014/2015), according to the four competition levels established with African mahogany trees in AFS installed in the municipality of Tomé Açu, with cupuassu and African mahogany trees. Belém - PA, 2019.

Tabela 1 - Produção média de frutos do cupuaçuzeiro, em $\mathrm{kg} / \mathrm{planta}$, nas últimas cinco safras (2010/2011 a 2014/2015), por níveis de competição com mogno africano estabelecido, em um SAF no município de Tomé Açu com cupuaçuzeiro e mogno africano. Belém - PA, 2019.

\begin{tabular}{lll}
\hline Level & \multicolumn{3}{c}{ Production* } \\
\hline 1 & 14.89 & $\mathrm{a}$ \\
2 & 15.37 & $\mathrm{a}$ \\
3 & 16.38 & $\mathrm{a}$ \\
4 & 18.44 & $\mathrm{a}$ \\
\hline Mean & 16.27 & \\
V.C. $(\%)$ & 27.53 & \\
\hline
\end{tabular}

Caption: Level $1=3.6 \mathrm{~m}$; Level $2=6.7 \mathrm{~m}$; Level $3=9.2 \mathrm{~m}$; Level $4=13.4 \mathrm{~m}$.

Source: Embrapa Amazônia Oriental.

* Averages followed by the same letter do not differ from each other at $5 \%$ significance by the Tukey test.

Legenda: Nível 1 = 3,6 m; Nível 2 = 6,7 m; Nível 3 = 9,2 m; Nível 4 = 13,4 m Fonte: Embrapa Amazônia Oriental

* Médias seguidas da mesma letra não diferenciam-se entre si à 5\% de significância, pelo teste Tukey. among the four levels was observed (Table 1). However, the average production was well below the two initial harvests of this series (2010/2011 and 2011/2012). This result indicated that competition between mahogany and cupuassu trees became widespread. With competition intensification, even the most distant plants were affected, with production reduction of more than $50 \%$ in relation to the two previous harvests.

African mahogany, in addition to promoting widespread reduction in cupuassu fruit production, also affected the vegetative development of plants, leading them to death. In the last year, the average mortality rate was $28 \%$ in the nearest plants (levels 1, 2 and 3), while only $15 \%$ in the more distant plants (level 4 ).

On the other hand, the vegetative development of mahogany plants was rapid and vigorous. The height of plants had linear growth until the fourth year of planting, with average increments around three meters per year (Figure 3). In the following years, growth was smaller, with increments around one meter.

Diameter at breast height - DBH increased from 9 $\mathrm{cm}$ in the first year to $60 \mathrm{~cm}$ in the $11^{\text {th }}$ year of field (Figure 4), when many plants reached the diameter for use in sawmills. Like height, $\mathrm{DBH}$ also had a linear increase in the first years, reaching, in the seventh year, average of $50 \mathrm{~cm}$. In the last four years of field, this increase was less pronounced, around $2.5 \mathrm{~cm}$ per year, on average. In the last year of trial, the average volume was $1,59 \mathrm{~m}^{3} /$ plant, with a yield of $63,77 \mathrm{~m}^{3}$ of wood per hectare.

The average canopy diameter was $12 \mathrm{~m}$ in the $11^{\text {th }}$ year of field, projecting shade to an average area of $137 \mathrm{~m}^{2}$, with clear tendency to continue increasing in the next years at estimated rate of $17 \mathrm{~m}^{2}$ per year. This great growing showed by the mahogany tree may have contributed to the decrease in the production of cupuassu trees, in the last years of trial.

Studying the productive yield behavior of both species in the years of cultivation (Figure 4), it was possible to observe two distinct moments. In the first moment (2008-2011), the yields of both cupuassu and African mahogany were increasing. During this period, the competition between the species was mild, not significantly affecting the plants performance. The cupuassu tree was well adapted to the shade conditions offered by African mahogany, and the competition under the ground was low, mainly due to the water supply offered

Revista Árvore 2020;44:e4407 


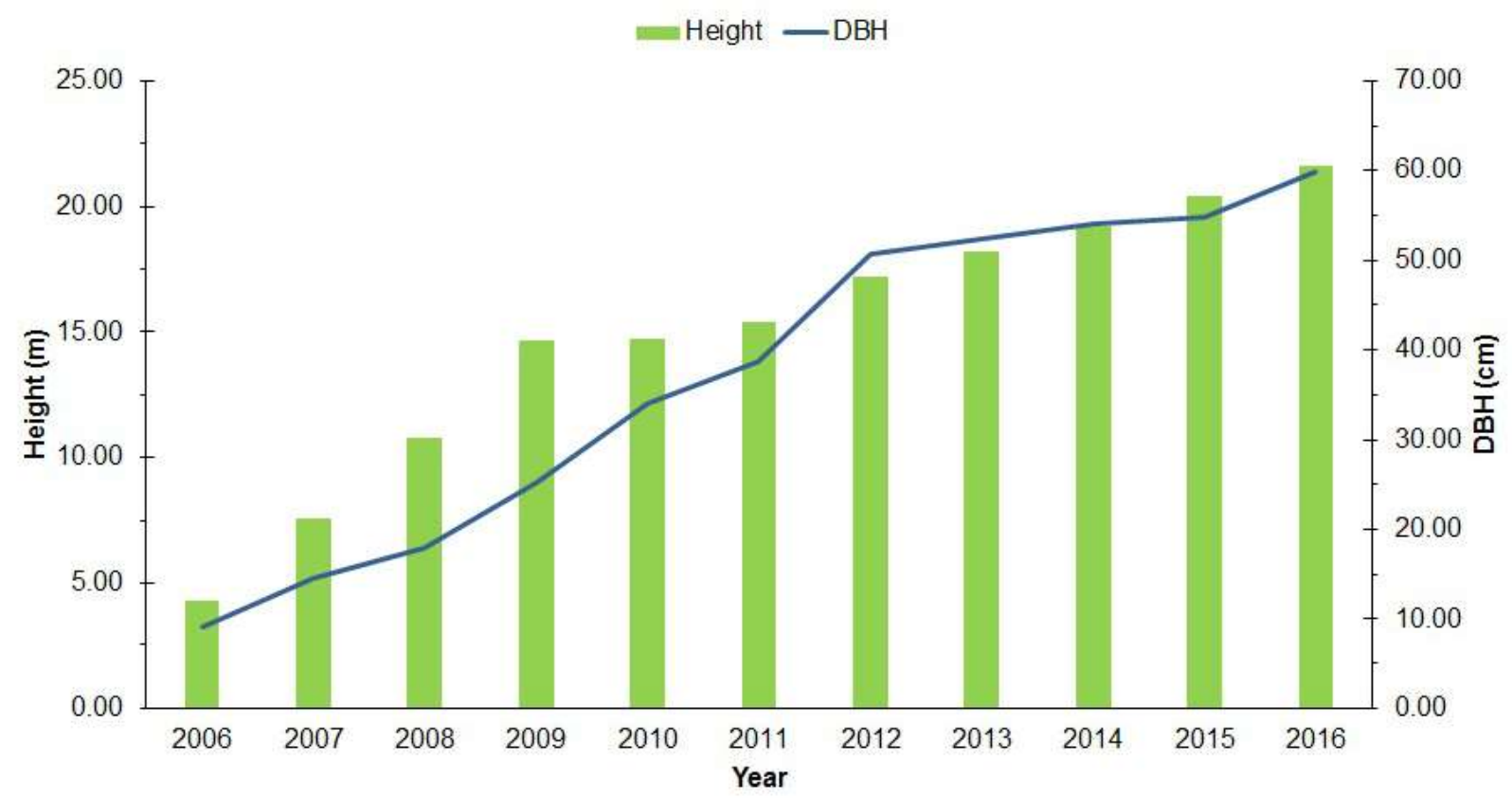

Figure 3 - Height (m) and Diameter at Breast Height (DBH) $(\mathrm{cm})$ evolution on African mahogany trees in the first eleven years of field in AFS installed in Tomé Açu, with cupuassu and African mahogany trees. Belém - PA, 2019.

Figura 3 - Evolução da Altura $(\mathrm{m})$ e Diâmetro à altura do peito $(D A P)(\mathrm{cm})$ em árvores de mogno africano nos primeiros onze anos de campo, em um SAF no município de Tomé Açu com cupuaçuzeiro e mogno africano. Belém - PA, 2019.

through irrigation in the water deficit months. However, in the second moment (2012-2016), there was a sharp drop in the productivity of cupuassu tree, as opposed to the steady increase in African mahogany yield. In this period, there was intensification of competition between both species, both over soil, for light, and under soil, for nutrients and, mainly, water, since the irrigation system was removed from the experimental area in 2011. From this year on, there was a progressive increase in the cupuassu tree mortality rate. Given this scenario, the tendency is that, in the coming years, there will be a constant reduction in cupuassu tree productivity, until it does not justify, economically, its permanence in the system, so that only African mahogany should stay.

\section{DISCUSSION}

In an agroforestry system, component species are in intense interaction. These relationships are influenced by factors intrinsic to plants such as root development, growth rate, canopy development, and suitability for consortium; and extrinsic to plants, such as spacing, water and nutrient availability and cultural treatments (Barros et al., 2009). According to Giustina et al. (2017), in systems composed by arboreal species, there is great competition for light, both quantitatively and qualitatively. However, Fletcher et al. (2012) point out that competition for water and nutrients under the soil has greater influence on the development of intercropped plants in relation to solar irradiation.

The vegetative development of plants is one of the first characteristics to be perceived when there is competition among individuals that compose a system. The spacing in which the system was implanted rules the intensity of these relationships. In general, there is a direct relationship between plant diameter and spacing, which can also be observed in monocultures (Feldpausch et al., 2011). Knowledge of this relationship and how it can affect productivity is of great importance for the management of AFSs, both in implementation and maintenance. Generally, height is not strongly influenced by spacing (Leles et al., 2011). It is noteworthy that the plants age can also influence the relantionship

Revista Árvore 2020;44:e4407 
Source: Embrapa Amazônia Oriental.

Fonte: Embrapa Amazônia Oriental.

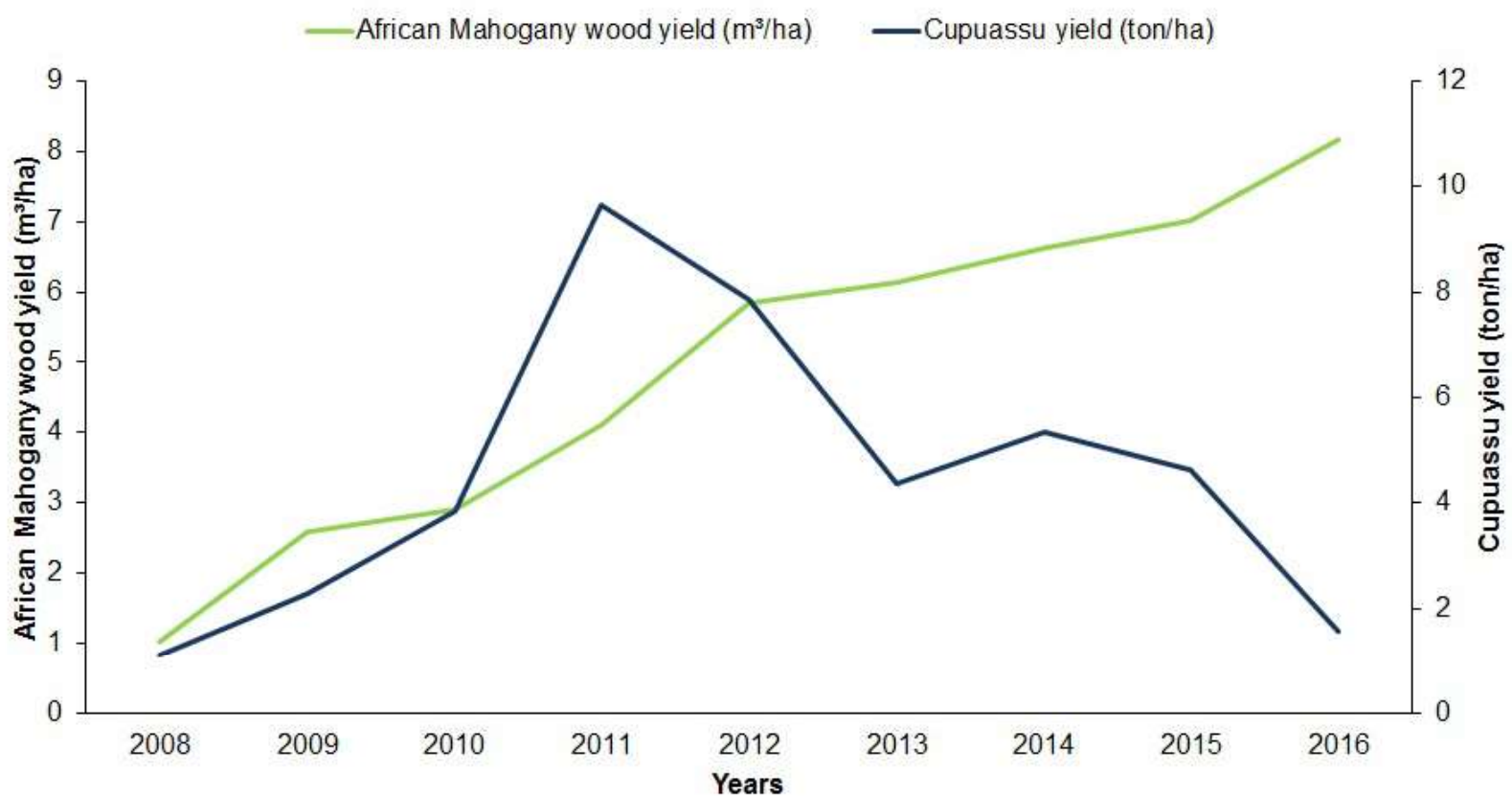

Figure 4 - African mahogany wood yield ( $\mathrm{m}^{3} / \mathrm{ha}$ ) and cupuassu yield (ton/ha) evolution in the last nine years of field in a agroforestry system installed in Tomé Açu. Belém - PA, 2019.

Figura 4 -Evolução da produção de madeira $\left(\mathrm{m}^{3} / \mathrm{ha}\right)$, pelo mogno africano, e de cupuaçu (ton/ha), pelo cupuaçuzeiro, nos útlimos nove anos de campo, em um sistema agroflorestal instalado em Tomé-Açu. Belém - Pa, 2019

intensity among species. Lunz et al. (2011) compared coffee tree cultivars in monoculture and in agroforestry system composed of açaí and andiroba and observed no significant differences in the vegetative development of coffee trees, possibly due to the young age of species that composed the system, which did not provide severe competition with coffee plants.

It is worth highlighting the excellent adaptation and development of African mahogany under the conditions of this study. In an agroforestry system in Rondônia, cited by Virgulino et al. (2015), was observed an average $\mathrm{DBH}$ value of $30.7 \mathrm{~cm}$, lower than the value found in the present study, which demonstrates the species' great adaptability to the Tomé Açu region.

Cupuassu tree is very sensitive to water deficit(Alves et al., 2018). In places like Tomé Açu - PA that shows significant rainfall reduction in the period from June to November, there is need for water supplementation. It was observed in the present study that, in the first years of AFS establishment, the vegetative development and production of cupuassu trees were not affected by competition with African mahogany, inferring that in the initial phase of cultivation, both species lived together harmoniously. It should be noted that in the first years, water supplementation was done in the critical months, which may have mitigated the effects of competition between species.

Competition between mahogany and cupuassu tree was only evident after the fifth year of field, when probably roots began to compete for water and nutrients. In the same way, shading promoted by African mahogany also affected the behavior of cupuassu trees. Competition with the other AFS species and lack of irrigation during this critical period led to a decrease in the production of cupuassu trees, reducing the survival rate. Thus, water supply provided in the necessary period will mitigate the effect of competition for water and, certainly, the response of cupuassu trees will be different.

Alves et al. (2018) observed that during the first years of AFS cultivation involving Spondias mombin L. and cupuassu trees, there was no damage for cupuassu trees in both vegetative development and fruit

Revista Árvore 2020;44:e4407 
production. However, with the plants development, it was possible to observe slight depression in fruit production; however, these losses were far behind the AFS overall benefits.

Anglaaere et al. (2011) point out that in cacao trees intercropped with African mahogany, excessive shading and humidity, in addition to lack of ventilation, led to the appearance of phytosanitary problems. In addition, the authors classified species of the genus Khaya, including African mahogany, as species of dense and broad canopy, with large leaves, thus species that provide great shading. Alves and Ferreira (2012) point out that the cupuassu tree tolerates up to approximately $25 \%$ shading without restricting productive performance. Therefore, as shading and competition for water and nutrients exerced by African mahogany trees become intensified, it will physiologically affect cupuassu trees.

Seoane et al. (2014) emphasize the importance of stratified exploitation of resources over and under the soil. The use of species that explore strata of the same level, or near levels, may compromise the performance of at least one of them. The superiority of the mahogany root system associated with the lack of basic cultural practices may have contributed to the decrease in the performance of cupuassu trees in the present study.

Similarly, Müller and Gama-Rodrigues (2007) pointed out that the consortium of cacao with rubber tree, a large-size forest species such as African mahogany, is not recommended because it provides light (excessive shading) and root competition (for water and nutrients), culminating by reducing cacao yield.

Even if there is some damage to sub-canopy species, agroforestry systems are still excellent alternatives, considering the long run. The species diversification (Varela and Santana, 2009) and the use of AFSs for legal reserve areas (Rodrigues et al., 2007; Brasil, 2012) make them excellent options, mainly for small producers. Magalhães et al. (2014) point out the great influence of wood saling on the AFS economic viability, since profits from this product can decrease the implantation costs.

\section{CONCLUSIONS}

In AFSs composed of African mahogany and cupuassu trees, negative influence of the first on the second species should be expected. However, further studies are needed to evaluate whether the rapid and consistent development of African mahogany, as observed here, economically compensates for the decline in cupuassu trees' production.

\section{REFERENCES}

Abdo MTVN, Valeri SV, Martins ALM. Sistemas agroflorestais e agricultura familiar: uma parceria interessante. Revista Tecnologia \& Inovação Agropecuária. 2008;1(2):50-59. Available: www.researchgate.net/profile/Maria_Teresa Abdo/publication/261706306_SISTEMAS_ AGROFLORESTAIS_E_AGRICULTURA_FAMILIAR_UMA_PARCERIA_INTERESSANTE/ links/00b7d $\overline{5} 35175 \overline{f a} 47 \mathrm{~cd} 3000000$. .pdf

Alves RM, Ferreira FN. BRS Carimbó: a nova cultivar de cupuaçuzeiro da Embrapa Amazônia Oriental. Embrapa Amazônia Oriental - Comunicado Técnico. 2012. Available: https://www.infoteca.cnptia.embrapa. br/bitstream/doc/918443/1/COM232.pdf

Alves RM, Bastos AJR, Chaves SFS, Fernandes JRQ. Spondias mombin and Theobroma grandiflorum in agroforestry system: productivity implications. Revista Brasileira de Fruticultura, 2018;40(6). Available: http://www.scielo.br/pdf/rbf/v40n6/0100-2945-rbf-406-e-061.pdf

Alvim PT. Agricultura apropriada para uso contínuo dos solos na Região Amazônica. Espaço, ambiente e planejamento, 1990;2(11):3-71. Available: http://sidalc. net/cgibin/wxis.exe/?IsisScript=AGB.

Anglaaere LC, Cobbina J, Sinclair FL, McDonald MA. The effect of land use systems on tree diversity: farmer preference and species composition of cocoabased agroecosystems in Ghana. Agroforestry systems, 2011;81(3):249-265. Doi: 10.1007/s10457-010-9366-Z

Arco-Verde MF. Sustentabilidade biofísica e socieconômica de sistemas agroflorestais na Amazônia brasileira. Tese (Doutorado em Ciências Florestais) - Universidade Federal do Paraná, Curitiba. 2008. Available: https://acervodigital.ufpr.br/ handle/1884/14429.

Barros AVL, Homma AKO, Takamatsu JA, Takamatsu T, Konagano M. Evolução e percepção dos sistemas agroflorestais desenvolvidos pelos agricultores nipobrasileiros do município de Tomé-Açu, estado do Pará.

Revista Árvore 2020;44:e4407 
Amazônia: Ciência e Desenvolvimento, 2009;5(9):121151. Available: https://www.alice.cnptia.embrapa.br/ alice/bitstream/doc/783288/1/EvolucaoePercepcaodo.pdf

Bolfe É. L., Batistella M. Análise florística e estrutural de sistemas silviagrícolas em Tomé-Açu, Pará. Pesquisa Agropecuária Brasileira, 2011; 46(10):1139-1147. Available: http://seer.sct.embrapa.br/index.php/pab/ article/view/8508/6622

Brasil. Lei n ${ }^{0} 12.615$, de 25 de maio de 2012. Dispõe sobre a proteção da vegetação nativa; altera as Leis nos 6.938, de 31 de agosto de 1981, 9.393, de 19 de dezembro de 1996, e 11.428 , de 22 de dezembro de 2006; revoga as Leis nos 4.771, de 15 de setembro de 1965, e 7.754, de 14 de abril de 1989, e a Medida Provisória no 2.166-67, de 24 de agosto de 2001; e dá outras providências. (D.O.U. DE 28.05.2012). Available: http://www.planalto.gov.br/ccivil_03/_ Ato2011-2014/2012/Lei/L12651.htm

Chase M. W., Christenhusz M. J. M., Fay M. F., Byng, J. W., Judd W. S., Soltis D. E., et al. An update of the Angiosperm Phylogeny Group classification for the orders and families of flowering plants: APG IV. Botanical Journal of the Linnean Society, 2016;181(1):1-20. Available: https://academic.oup.com/ botlinnean/article/181/1/1/2416499

Castro AC, Lourenço Júnior JB, Santos N, Monteiro EMM, Garcia AR. Sistema silvipastoril na Amazônia: ferramenta para elevar o desempenho produtivo de búfalos. Ciência Rural, 2008;38(8):23952402. Available: https://www.redalyc.org/ pdf/331/33113633050.pdf

Cruz CD. Genes: a software package for analysis in experimental statistics and quantitative genetics. Acta Scientiarum. Agronomy, 2013;35(3):271-276. Doi: 10.4025/actasciagron.v35i3.21251

Falesi IC; Baena ARC. Mogno-africano (Khaya ivorensis A. Chev.) em sistema silvipastoril com leguminosa e revestimento natural do solo. Embrapa Amazônia Oriental-Documentos, 1999. Available: https://www.infoteca.cnptia.embrapa.br/bitstream/ doc/388796/1/OrientalDoc4.pdf

Feldpausch TR, Banin L, Phillips OL, Baker TR, Lewis SL, Quesada CA, et al. Height-diameter allometry of tropical forest trees. Biogeosciences, 2011;8:77277793. Doi: 10.5194/bg-8-1081-2011.

Fletcher EH, Thetford M, Sharma J, Jose S. Effect of root competition and shade on survival and growth of nine woody plant taxa within a pecan [Carya illinoinensis (Wangenh.) C. Koch] alleycropping system. Agroforestry systems, 2012;86(1):49-60. Doi: 10.1007/s10457-012-9507-7.

França TSFA, Arantes MDC, Paes JB, Vidaurre GB, Oliveira JTS, Baraúna EEP. Características anatômicas e propriedades físico-mecânicas das madeiras de duas espécies de mogno africano. Cerne, 2015;21(4):633640. Doi: 10.1590/01047760201521041877

Genovese MI, Lannes SCS. Comparison of total phenolic content and antiradical capacity of powders and" chocolates" from cocoa and cupuassu. Food Science and Technology, 2009;29(4):810-814. Doi: 10.1590/S0101-20612009000400017.

Giustina CD, Carnevalli RA, Romano MR, Antonio DBA, Eckstein C. Growth of different fruit tree species in silvopastoral systems during the establishment phase. Revista Caatinga, 2017;30(4):1040-1049. Available: http://www.scielo.br/pdf/rcaat/v30n4/1983-2125rcaat-30-04-01040.pdf.

Leles PSS, Abaurre GW, Alonso JM, Nascimento DF, Lisboa AC. Crescimento de espécies arbóreas sob diferentes espaçamentos em plantio de recomposição florestal. Sci. For. 2011;39(90):231-239. Available: https://www.researchgate.net/profile/Jorge_Alonso16/ publication/291803994_Grownth_of_tree_species in_defferent_planting_spacing_for_forest_recovery/ links/5a33b869a6fdcc9b2d788e29/Grownth-of-treespecies-in-defferent-planting-spacing-for-forestrecovery.pdf

Lunz, AM, Thomazini MJ, Moraes MCB, Neves EJM, Batista TFC, Degenhardt J, et al. Hypsipyla grandella em mogno (Swietenia macrophylla): situação atual e perspectivas. Pesquisa Florestal Brasileira, 2009;59:4555. Doi: 10.4336/2009.pfb.59.45.

Lunz AMP, Sales FD, Silva Junior EC, Andrade Neto RDC, Morais FM, Machado M. Avaliação do cafeeiro em monocultivo e em sistema agroflorestal com açaí 
e andiroba. In: CONGRESSO BRASILEIRO DE SISTEMAS AGROFLORESTAIS, 8., 2011, Belém, PA. Sistemas agroflorestais na paisagem florestal: desafios científicos, tecnológicos e de políticas para integrar benefícios e globais: anais. Belém, PA: SBSAF: Embrapa Amazônia Oriental: UFRA: CEPLAC: EMATER: ICRAF, 2011. Available: https:/www.alice.cnptia.embrapa.br/bitstream/ doc/912253/1/24075.PDF

MacDicken KG, Vergara NT. Agroforestry: classification and management. New York: John Wiley \& Sons; 1990. ISBN: 0471837814

Magalhães JGS, Silva ML, Salles TT, Rego LJS. Análise econômica de sistemas agroflorestais via uso de equações diferenciais. Revista Árvore, 2014;30(1):73-79. Available: https://www.redalyc.org/ articulo.oa?id=48830661007.

Müller MW, Gama-Rodrigues AC. Sistemas Agroflorestais com cacaueiro. Ciência, Tecnologia e Manejo do Cacaueiro. CEPLAC/CEPEC, 2007; 246271. Available: https://www.researchgate.net/profile/ Antonio_Gama-Rodrigues/publication/290157741_ Sistemas_Agroflorestais_com_Cacaueiro/ links/5695025c08ae3ad8e 33d $4028 . p d f$

Oliveira TB, Genovese, MI. Chemical composition of cupuassu (Theobroma grandiflorum) and cocoa (Theobroma cacao) liquors and their effects on streptozotocin-induced diabetic rats. Food research international, 2013; 51(2), 929-935. doi: 10.1016/j. foodres.2013.02.019

Pachêco NA, Bastos TX. Caracterização climática do município de Tomé-Açu, PA. Embrapa Amazônia Oriental-Documentos (INFOTECA-E). 2001. Available: https://www.infoteca.cnptia.embrapa.br/ infoteca/handle/doc/403414

Rodrigues ER, Cullen Júnior L, Beltrame TP, Moscogliato AV, Silva IV. Avaliação econômica de sistemas agroflorestais implantados para recuperação de reserva legal no Pontal do Paranapanema, São Paulo. Revista Árvore, 2007;31(5):941-948. Available: http://www.redalyc.org/articulo.oa?id=48831518.

Sanguino AC, Santana AC, Homma AKO, Barros PLC, Kato OK, Amin MMGH. Avaliação econômica de sistemas agroflorestais no estado do Pará. Amazonian Journal of Agricultural and Environmental Sciences, 2007;47(1):71-88. Available: http://ajaes.ufra.edu.br/ index.php/ajaes/article/view/196/85.

Seoane C, Froufe L, Amaral-silva J, Arantes ACV, Steenbock W. Conservação ambiental forte alcançada através de sistemas agroflorestais multiestratificados: 1-agroflorestas e a restauração ecológica de florestas. Cadernos de Agroecologia, 2014;9(4). Available: https://www.alice.cnptia. embrapa.br/alice/bitstream/doc/1018264/1/2014C. EduardoAGROECOLConservacao11.pdf

Silva LF, Ferreira GL, Santos ACA, Leite HG, Silva ML. Equações hipsométricas, volumétricas e de crescimento para Khaya ivorensis plantada em Pirapora. Floresta e Ambiente, 2016; 23(3):362-368. Doi: 2179-8087.130715.

Soares SD. Diversidade genética em população de melhoramento de mogno africano (Khaya ivorensis A. Chev.). Dissertação (Mestrado em Genética e Biologia Molecular) - Universidade Federal de Goiás, Goiânia. 2014. Available: https://repositorio.bc.ufg.br/tede/ handle/tede/4544

Varela LB, Santana AC. Aspectos econômicos da produção e do risco nos sistemas agroflorestais e nos sistemas tradicionais de produção agrícola em Tomé-açu, Pará-2001 a 2003. Revista Árvore, 2009;33(1):151-160. Available: http:/www.scielo.br/ pdf/rarv/v33n1/v33n1a16

Venturieri GA. Flowering levels, harvest season and yields of cupuassu (Theobroma grandiflorum). Acta Amazonica, 2011;41(1): 143-152. Doi: 10.1590/S004459672011000100017.

Verzignassi JR, Poltronieri LS, Benchimol RL. Mancha-alvo em mogno-africano no Brasil. Summa Phytopathologica, 2009;35(1):70-71. Doi: 10.1590/ S0100-54052009000100015.

Virgulino AP; Santos JS; Corrêa FLO; Müller MW. Análise do valor produtivo de espécies florestais em um sistema agroflorestal, Rondônia, Brasil. Revista Agrotrópica, 2015;27(2), 167-172. Doi: 10.21757/0103-3816.2015v27n2p167-172.

\section{Revista Árvore 2020;44:e4407}

